International Journal of Agriculture, Environment and Bioresearch

Vol. 06, No. 03; 2021

ISSN: $2456-8643$

\title{
PAPAYA MEALY BUG, ITS HOST RANGE, BIOLOGY AND MANAGEMENT
}

\author{
V Ramalakshmi ,Lipsa Das and Deepayan Padhy \\ * Assistant professor, Department of Entomology, M. S. Swaminathan School of Agriculture, Centurion University \\ of Technology and Management, Paralakhemundi, Dist-Gajapathi, Odisha - 761211.
}

https://doi.org/10.35410/IJAEB.2021.5629

\begin{abstract}
Papaya is attacked by various arthropods pests like fruit flies, whiteflies, aphids and mealy bugs. Among these The papaya mealybug, Paracoccus marginatus is a invasive pest. Papaya mealybug, is a small, soft bodied insect pest belongs to the Family Pseudococcidae under the subOrder homoptera. Invasion of papaya mealybug in Asia was first reported from Java, Indonesia and Tamil Nadu in India during 2008. It can cause direct damage by feeding on various plant parts and as well they also inject toxic saliva into plant tissues, excrete honey dew it leads to the growth of sooty mould fungus and photosynthetic activity of plant will be reduced. At the time of feeding, it injects a toxin into the plant which causes chlorosis, stunting, leaf deformation and heavy build-up of honeydew ultimately leading to the death of the plant. In order to understand more about the biology, host range, damaging symptoms and their management this review article has been written.
\end{abstract}

Keywords: Invasive pests, mealy bug, host range and papaya.

\section{INTRODUCTION}

Papaya fruit is a rich supply of nutrients such as provitamin A, carotenoids, vitamin C, folate and dietary fiber. Papaya skin, pulp and seeds also contain a variety of phytochemicals, including lycopene and polyphenols. The ripe fruit of the papaya is usually eaten raw, without skin or seeds. Fruit quality for fresh market is important; therefore arthropods that blemish the fruit skin, enter the fruit, or feed on the pulp or seeds can cause high losses and are considered of economic importance. papaya is attacked by various arthropods like fruit flies, whiteflies, aphids and mealy bugs. Among these papaya mealybug, Paracoccus marginatus Williams and Granara de Willink is a small, soft bodied insect pest belongs to the Family Pseudococcidae under the Order Hemiptera. According to Williams et al., (1992), Paracoccus marginatus was first recorded in Mexico during 1955. Walker et al., (2003) stated that Paracoccus marginatus was recorded from the 14 Caribbean countries. Invasion of papaya mealybug in Asia was first reported by from Java, Indonesia and Tamil Nadu in India (Muniappan et al., 2008). Papaya mealybug was first reported in Bangladesh in 2009 (Muniappan, 2010). Within a short period of time, the papaya mealybug is now spread all over the country. The papaya mealybug, Paracoccus marginatus feeds on the sap of plants by inserting its stylets into the epidermis of the leaf and also into fruits and stem. At the time of feeding, it injects a toxin into the plant which causes chlorosis, stunting, leaf deformation and heavy build-up of honeydew ultimately leading to the death of the plant. Honey dew produced by this bug results in the development of sooty mould that covers the 
Vol. 06, No. 03; 2021

ISSN: $2456-8643$

leaves, fruits and stems, obstructing photosynthesis and gaseous exchange. Heavy infestations are capable of rendering fruit inedible due to the buildup of thick white wax. Heavily attacked plants were killed (Walker et al., 2003; Hue et al., 2007). The papaya mealybug, Paracoccus marginatus is a noxious insect pest it has wide host range attacking papaya and other agricultural plants of economic importance (Miller \& Miller, 2002). Heavy attack of papaya mealybug has been noticed on wider range of cultivated crops and weed hosts belonging to different families of plant kingdom. Host plants from Cultivated agricultural and horticultural crops are Cajanus cajan L(Leguminaceae), Gossypium hirsutum L. (Malvaceae), Jatropha curcus L. (Euphorbiaceae), Morus alba L. (Moraceae), Psidium guajava L. (Myrtaceae), Lycopersicon esculentum Mill. (Solanaceae), Tectona grandis L. (Verbanaceae) and weed host like Abutilon indicum L.( Malvaceae), Achyranthus aspera L(Amaranthaceae), Cleome viscosa L. (Capridaceae), Commelina benghalensis L.( Commelinaceae), Convolvulus arvensis L. (Convolvulaceae), Euphorbia hirta L. (Euphorbiaceae), Leucas aspera (Willd) Lamiaceae, Parthenium hysterophorus L. (Asteraceae), Tridax procumbens L. (Compositae), Trianthema portulacastrum L.( Aizoaceae), Canthium inerme (L.f.) Kuntze (Rubiaceae ) in these plants attack was noticed

\section{Biology}

Papaya mealybugs are very active during dry and warm weather. Females don't have wings, and move by crawling short distances or by being blow in air currents. Females can lay 100 to 600 eggs. Greenish yellow colored eggs are laid in an ovisac sac that is three to four times the body length and totally covered with white wax material and it is located ventrally in female insect.. Egg-laying continuous over a period of one to two weeks. Eggs hatch in about 10 days, and nymphs or crawlers begin to actively search for feeding sites. Adult males may be distinguished from other related species by the presence of stout fleshy setae on the antennae and the absence of fleshy setae on the legs. Females have three instars whereas males have four instars. Males have longer development time (27-30 days) than females (24-26 days) at 25 $\pm 10 \mathrm{C}, 65 \pm 2 \% \mathrm{RH}$ and 12:12 (L:D) photoperiod. Adult females attract the males with sex pheromones. Under protected conditions, reproduction occurs throughout the year.

\section{Management}

\section{Cultural and Mechanical}

Monitoring and exploration to detect early presence of the mealybug, exclusion of weeds/alternate host plants like Hibiscus, Parthenium etc. in and nearby crop. use of sticky bands or alkathene sheet or on main stem to prevent movement of crawlers

\section{Biological control}

Release of imported encyrtid parasitoids such as Acerophagous papayae, Anagyrus loecki and Pseudoleptomastix mexicana is being presently used to manage papaya mealybug. Among them A. papayae was successfully eliminated the papaya mealy bug population. It attacks the mealy 
Vol. 06, No. 03; 2021

ISSN: $2456-8643$

bugs in two ways. The adult wasp punctures a mealybug and extracts fluid from the wound. The female wasp feeds on the fluid of the drying mealybug, which provides nutrient to wasp's eggs for development. Fully developed adult wasp comes out of the mummy of the mealybug by cutting a circular hole in the end of the mummy and crawls out. The use of exotic natural enemies to suppress pest population has long been an integral part of biological control, which has continually proved very valuable in eliminating pest problems (Van Driesche R.G. and Bellows, T.S., 1996). The present results indicated that A. papayae was very effective in reducing mealybug population in parasitoids released field when compared to unreleased field. The present results are in close agreement with the findings of Sakthivel., 2013 who reported that the population of papaya mealybug was found to decrease considerably with an increase in per cent parasitisation. Muniappan et al.,2006 reported that four months after introduction of the parasitoids there was significant reduction in $P$. marginatus. Shylesha et al.,2010 Krishnamoorthy et al.,2011 and Qadri,2011, reported that the parasitoid A. papayae was observed in few numbers at 20 days after release and the spread of the parasitoid was very good by 40 and 60th day of release. After a span of three months, there was a reduction of $80-90 \%$ in pest population. Pokharkar et al.,2011 and Nakat et al.,2011 reported that there was 85-92\% reduction in mealybug population within three months after releasing the parasitoid A. papayae.

\section{Chemical control}

Regular monitoring of the crop for mealybug infestation and its natural Enemies, Spot application of insecticide immediately after noticing mealybug on some plants in the crop field. If the activities of natural enemies are not observed, use of botanical insecticides such as neem oil (1 to $2 \%$ ), NSKE (5\%), or Fish Oil Rosin Soap(25g/litre of water) should be the first choice .Apply recommended chemical insecticides as the last resort such as profenophos 50 EC (2

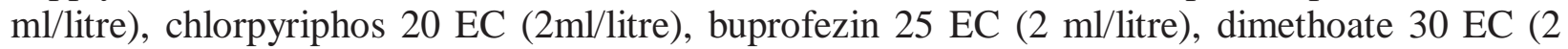
$\mathrm{ml} /$ litre), thiomethoxam $25 \mathrm{WG}(0.6 \mathrm{~g} / \mathrm{litre})$, imidacloprid $17.8 \mathrm{SL}$ (0.6 ml/litre).Drenching soil with chlorpyriphos around the collar region of the plant to prevent movement of crawlers of mealybug and ant activity is useful.

\section{CONCLUSION}

Papaya mealy bug is a invasive pest, it has more egg laying capacity and breeding occurs throughout the year in protected conditions. It has wide host range attacking various agricultural, horticultural and weeds also. In this regard it needs effective management practices like cultural ,biological and chemical methods .

\section{REFERENCES}

Heu RA., Fukada MT and Conant P (2007) Papaya mealybug, Paracoccus marginatus Williams and Granara de Willink(Hemiptera: Pseudococcidae). State of Hawaii New Pest Advisory. Department of Agriculture No. 04-03.

Krishnamoorthy, A., Mani, M., Gangavisalakshi, P.N. and GopalaKrishna pillai, K., Classical Biological Control of papaya mealybug, Paracoccus marginatus using exotic parasitoid Acerophagus papayae. Proceedings of national symposium on Harnessing biodiversity for biological 
Vol. 06, No. 03; 2021

ISSN: $2456-8643$

control of crop pests, abstract. NBAII, Bangalore, PP. 101. (2011).

Miller DR and Miller GL (2002) Redescription of Paracoccus marginatus Williams and Granara de Willink (Hemiptera:Coccoidea: Pseudococcidae), including descriptions of the immature stages and adult male. Proc. Entomol. Soc.Washington 104: 1-23.

Muniappan R (2010) Success story, Biological Control of papayamealybug. Accessed online 10 July 2012 at http://iapps2010: wordpress.com/2010/30/papayamealybug-in-Bangladesh.

Muniappan R, Shepard BM, Watson GW, Carner GR, Sartiami D, Rauf A and Hammig MD (2008) First report of the papaya mealybug, Paracoccus marginatus (Hemiptera:Pseudococcidae), in Indonesia and India. J. Agrl. Urban Entomol. 25: 37-40. DOI: 10.3954/1523-5475-25.1.37

Muniappan, R., Meyerdirk, D.E., Sengaebau, F.M., Berringer, D.D. and Reddy G.V.P., Classical biological control of papaya mealybug, Paracoccus marginatus Williams and Granara de Willink (Hemiptera: Pseudococcidae) in the republic of Palau. Flor. Ent., 89: 212-217 (2006).

Nakat, R.V., Pokharkar, D.S., Dhane, A.S. and Tamboli, N.D., Biological impact of Acerophagus papayae (Noyes and Schauff) on suppression of papaya mealybug, Paracoccus marginatus, Williamas and Granara de Willink in Pune region of Maharashtra. Proceedings of the National Symposium meeting on Strategies for deployment and impact of the imported parasitoids of papaya mealybug, Classical biological control of papaya mealybug ,Paracoccus marginatus in India. PP. 79-81 (2011).

Pokharkar, D.S., Nakat, R.V., Tamboli, N.D. and Dhane, A.S., Papaya mealybug, Paracoccus marginatus Williams and Granara de Willink (Hemiptera Pseudococcidae) and its natural enemies in Maharashtra. Proceedings of national symposium on Harnessing biodiversity for biological control of crop pests, abstracts. NBAII, Bangalore, PP.29. (2011).

Qadri, S.M.H., Central Silk Board initiatives in tackling in menace of papaya mealybug (Paracoccus marginatus) in Mulberry. Proceedings of the National Symposium meeting on Stretagies for deployment and impact of the imported parasitoids of papaya mealybug, Classical biological control of papaya mealybug, Paracoccus marginatus in India. PP. 47-50 (2011).

Sakthivel, N., Effectiveness of three introuduced encyrtid parasitic wasps (Acerophagus papayae, Anagyrus loecki and Pseudlptomastix mexicana) against papaya mealybug, Paracoccus marginatus infesting mulberry in Tamil Nadu. Jrnl. of Biopest, 6(1): 71-76 (2013).

Shylesha, A.N., Joshi, S., Rabindra, R.J. and Bhumannavar, B.S., Classical biological control of the papaya mealybug. Folder published from National Bureau of Agriculturally Important Insects, Bengaluru. (2010).

Van Driesche, R.G. and Bellows, T.S., Biological Control. Chapman \& Hall, New York. (1996). Walker A, Hoy M and Meyerdirk DE (2003) Papaya Mealybug. University of Florida Featured Creatures.http://creatures.ifas.ufl.edu/fruit/mealybugs/papaya_mealybug.htm (Accessed on 29 Sept 2008).

Williams DJ and Granara de Wilink MC (1992) Mealybugs of Central and South America, CAB International, Wallingford, England, 635. 